\title{
ORIGINAL ARTICLE \\ Activity and foraging efficiency of the aerial insectivorous bat Molossus molossus (Molossidae) in Brazilian Atlantic Forest
}

\author{
Gustavo Pena Freitas ${ }^{1}$, William Douglas Carvalho ${ }^{1,2}$, Luciana Moraes Costa ${ }^{1,3,{ }^{*}}$, Carlos Eduardo Lustosa \\ Esbérard $^{1}$
}

\author{
${ }^{1}$ Laboratório de Diversidade de \\ Morcegos, Departamento de Biologia \\ Animal, Instituto de Biologia, \\ Universidade Federal Rural do Rio \\ de Janeiro, CP 74507, 23890-000, \\ Seropédica, RJ, Brazil. \\ 2 Programa de Pós-Graduação em \\ Biodiversidade Tropical, Universidade \\ Federal do Amapá, 68903-419, Rod. \\ Juscelino Kubitscheck, S/N - Jardim \\ Marco Zero, Macapá, AP, Brazil. \\ ${ }^{3}$ Laboratório de Ecologia de \\ Mamíferos, Departamento de Ecologia, \\ Instituto de Biologia, Universidade do \\ Estado do Rio de Janeiro, 20550-013, Rua \\ São Francisco Xavier, 524, Rio de Janeiro, \\ RJ, Brazil. \\ *Corresponding author: \\ costalucianam@gmail.com
}

\begin{abstract}
Activity outside day roosts among insectivorous bat species can vary considerably and has been linked to feeding habits. We aimed to assess time of emergence, duration of activity, and foraging efficiency in a Brazilian population of Molossus molossus. We also investigated if body mass gain was related to foraging amplitude and night length. We achieved 592 first-time captures and recaptures of 248 adult individuals. The bats were predominantly crepuscular. Average duration of activity outside roosts was $36 \mathrm{~min}$. We found that individuals captured returning to their roosts were significantly heavier (mean $=0.80 \mathrm{~g}$ ) than those upon emergence, equating to average consumption of $\sim 22 \mathrm{mg} / \mathrm{min}$ insects during the bats' activity period. Although we only sampled the first of two periods of nightly activity for $M$. molossus, we show the importance of insectivorous bats for insect suppression, especially when insect abundance peaks during the summer. Further studies should focus on the potential for using bats as a biological control, given that Brazil has a globally significant agricultural economy.
\end{abstract}

DOI: https://doi.org/10.14709/BarbJ.13.1.2020.10

Keywords: Activity time, Atlantic Forest, foraging strategy, foraging efficiency, foraging trip, pest control.

\section{INTRODUCTION}

Several factors influence the activity time of a species, such as food availability, predation risk, altitude, and climate (Jones \& Rydell 1994, Kunz \& Anthony 1996, Esbérard \& Bergallo 2008, Dunn \& Waters 2012). Among insectivorous bats, activity time outside the day roost can vary considerably (Racey \& Swift 1985, Wai-Ping \& Fenton 1989, Audet 1990, Rydell 1993), being influenced by temperature, wind (Fenton et al. 1998), rain (McAney \& Fairley 1988, Audet 1990, Carvalho et al. 2011), cloud cover (Kunz \& Anthony 1996, Welbergen 2006), and moon phase (Esbérard 2007, Breviglieri 2011). Apart from these factors, activity time is related to feeding habits, with insectivorous bats tending to be more active soon after sunset and before sunrise and being less active in the intervening period, as well as throughout the day (Brown 1968, Esbérard \& Bergallo 2010, Costa et al. 2011, Holland et al. 2011). This bimodal activity pattern has been linked to peak insect activity (Rautenbach et al. 1988, Chase et al. 1991, Jones \& Rydell 1994).

The Molossidae and Vespertilionidae represent the primary insectivorous bat families in the Neotropics (see Nogueira et al. 2014, Reis et al. 2017). The Molossidae has the largest number of species ( $n=31$ ) (Nogueira et al. 2018), which commonly roost in human constructions, hollow trees, rock crevices, palm leaves, and caves (Nowak 1994, Pacheco et al. 2010, Biavatti et al. 2015, López-Baucells et al. 2017). Of the molossid bats in the Neotropics, Molossus molossus (Pallas 1766) is perhaps one of the best studied because it is relatively easy to capture upon emergence from its roosts and due to its abundance in urban areas and human constructions in forested areas (Esbérard 2011, Biavatti et al. 2015).

Molossus molossus is one of the most common bat species in the Neotropics (Esbérard \& Bergallo 2010). This small species exhibits a bimodal foraging activity pattern, with greater activity being displayed soon after sunset and before sunrise (Dechmann et al. 2010, Esbérard \& Bergallo 2010, Costa et al. 2011, Holland et al. 2011). Thus, more than one foraging flight can be taken in a given night, with durations of between 37.55 and 50 min in its first peak of activity (Dechmann et al. 2010, Holland et al. 2011), and averaging 82.2 min from dusk to dawn (Holland et al. 2011). M. molossus is an aerial insectivore (Barclay \& Brigham 1994, MacDonald 2001), typically feeding on small and crepuscular insects, mainly Coleoptera (representing approximately $45 \%$ 
of its diet) and Lepdoptera ( $12 \%)$, followed by Hemiptera (9\%), Hymenoptera ( 3\%), and Diptera ( 2\%) (RamírezChaves et al. 2008). The species is known to forage in groups (Dechmann et al. 2010).

According to Biavatti et al. (2015) and Xavier et al. (2018), it occasionally roosts with other bat species such as Molossus aztecus Saussure, 1860, M. rufus E. Geoffroy, 1805, Eumops auripendulis (Shaw, 1800), Eumops perotis (Schinz, 1821), Myotis nigricans (Schinz, 1821), Eptesicus furinalis (D'Orbigny \& Gervais, 1847), Histiotus velatus (I. Geoffroy, 1824), Phyllostomus hastatus (Pallas, 1767), and Tonatia bidens (Spix, 1823). Regarding its reproductive cycle, this species presents well-characterized polyestrous, with pregnant females and newborn young being recorded in the months of March-April and November in northeastern Brazil (Fabián \& Marques 1989). In southeastern Brazil, pregnant and lactating females can be found between November and March (Freitas 2012). Sperm production is concentrated in the hottest and wettest period of the year (Barros et al. 2013, Christante et al. 2013, Arandas 2018), but males can be sexually active throughout the year (Fabián \& Marques 1989, Freitas 2012).

Here, the aims of our study were to: (i) assess time of emergence, (ii) activity duration, and (iii) foraging efficiency for a population of $M$. molossus on an island in the southeastern Brazilian Atlantic Forest. In addition, (iv) we investigate if body mass gain is related to foraging amplitude and night length on capture nights. We expected the $M$. molossus population studied to display crepuscular activity, as previously reported elsewhere (Holland et al. 2011). As summer nights are warmer and shorter than winter nights, presenting a greater concentration of food availability, we expected $M$. molossus to exhibit greater body mass gain in the summer, coinciding with peak $M$. molossus reproductive activity (Esbérard 2011).

\section{MATERIALS AND METHODS}

\section{Study area}

The study was conducted at Gato Beach (Praia do Gato)

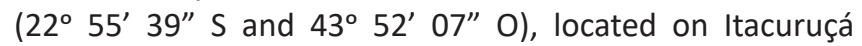
Island, within the municipalities of Itaguaí and Mangaratiba, in the Mangaratiba Environmental Protection Area. Gato Beach is surrounded by Atlantic Forest, classified as dense submontane rainforest (IBGE 1992). This area has a tropical rainy AW climate (Koeppen 1948). Average annual temperature is $23.7^{\circ} \mathrm{C}$, with February being the warmest month (average temperature of $26.8^{\circ} \mathrm{C}$ ) and August being the coldest (average temperature of $20.9{ }^{\circ} \mathrm{C}$ ). Average annual rainfall is $1,239.7 \mathrm{~mm}$, with $37 \%$ of rainfall occurring in the summer rainy season (October to March) and $15 \%$ in the winter dry season (April to September) (Mattos 2005, André et al. 2008). In the study region, nights of the rainy season are shorter (average of 656 minutes, 11 hours) than those of the dry season (average of 767 minutes, $\sim 13$ hours).

\section{Data collection}

We identified two diurnal roosts of $M$. molossus at Gato Beach, approximately $40 \mathrm{~m}$ apart from each other. One roost was located inside the roof lining of a house and the other was in a hollow mango tree (Mangifera indica, L., Anacardiaceae). Both roosts were adjacent to the beach and surrounded by primary Atlantic Forest vegetation. The roof lining covers approximately $190 \mathrm{~m}^{2}$, and bats access the roost through an opening located $\sim 5 \mathrm{~m}$ above ground. The mango tree is $\sim 10 \mathrm{~m}$ tall, but the entrance to the roost is located $\sim 2.5 \mathrm{~m}$ above ground. We considered these two roosts to be a single population due to their proximity and observed dual use by individuals (based on recaptures) throughout the sampling period. Mist-net sampling was conducted at roosts on 17 nights from September 2009 to August 2011, with a minimum interval of 40 days between capture nights to prevent bats from learning mist-net locations and to avoid excessive colony disruption (Esbérard 2006). We set mist nets $(9 \times 2.5 \mathrm{~m}$, mesh $19 \mathrm{~mm})$ approximately 0.5 meters from and at the same height as roost access points. The mist nets remained open from $\sim 1$ hour before sunset to midnight. Captured bats were placed in cloth bags and released after the mist nets had been closed so they would not be caught twice on the same night. If we had released the bats while mist nets were still open, we would have generated a bias in our data due to the influence of capture. Animal handling and processing was in accordance with guidelines for the use of wild mammals in research from the American Society of Mammalogists (Sikes \& ACUC 2016) and research permits issued by the Government of Brazil.

When we removed captured bats from the mist nets, we recorded the time and whether they were emerging from the roosts or returning to them. Captured bats were sexed (male or female), weighed (with an electronic weighing scales to within $0.1 \mathrm{~g}$ ), classified as adult or juvenile [based on the degree of ossification of the phalangeal epiphyses (Kunz \& Anthony 1982)], and their forearm length was measured (with calipers to within $0.1 \mathrm{~mm}$ ). All captured adult bats were individually and permanently marked with a numbered plastic necklace (Esbérard \& Daemon 1999) to identify recaptures. Juvenile individuals were not marked and were removed from the analysis. Since all captured bats were released at midnight, they were still able to forage.

\section{Data analyses}

Differences in emergence and return times between males and females were initially assessed using a $t$ test because, in some bat species, males can emerge later and return earlier than females (Kunz et al. 1998). However, as we detected no difference between the sexes for emergence $(t=-0.405 ; p=0.69)$ or return time $(t=-0.116 ; p=0.91)$, we pooled data from the sexes to carry out further analyses. We also assessed the difference in body mass between males and females upon roost emergence, as well as upon returning to roosts, but observed no significant differences (roost emergence: $t=1.937, \mathrm{p}=0.07$; roost return: $t=0.920$; $p=0.36)$. Thus, body mass data of males and females was pooled. We used $t$ tests for these comparisons because the data distributions were normal (Shapiro-Wilk test, $p$ > 0.05 ), and the variances were homogeneous (Levene test, $p>0.05)$.

We considered capture time of individuals emerging from the roosts to assess time of emergence. Since our data 
is circular (hours over a day), we adopted circular statistics, which is a better approach than analyzing such data as linear or categorical (see Oliveira-Santos et al. 2013). Thus, we used Rayleigh's test (R), which assesses the statistical significance of the average angle of a circular distribution (Zar 1996), to analyze bat emergence time.

To assess foraging time, we considered foraging amplitude (flight time or duration of foraging flight, Winter 1999), i.e., the difference between the time of capture of the first individual emerging from the roost and the time of capture of the last individual returning to the roost. To analyze foraging efficiency, we compared the average total body mass of animals entering the roost with those leaving the roost (representing body mass gain). For this, we used a $t$ test because the data distribution was normal (ShapiroWilk test, $p>0.05$ ) and the variance was homogeneous (Levene test, $p>0.05$ ).

To establish if body mass gain on capture nights (response variable) was related to foraging amplitude and night length up to midnight (explanatory variables), we performed a generalized linear model (GLM) selection with a gaussian error distribution and considering Akaike's Information Criterion corrected for small sample size (AICc, Burnham \& Anderson 2002), where the best candidate model was that with the smallest AICc value to predict body mass gain. For model selection, we disregarded capture nights on which fewer than five individuals were captured entering or leaving the roosts. Consequently, only 13 of 17 capture nights were assessed (i.e., excluding the $8^{\text {th }}, 15^{\text {th }}, 16^{\text {th }}$ and $17^{\text {th }}$ capture nights). Data are presented as mean values with standard deviations. A Spearman correlation matrix was generated to exclude possible bias from collinearity between foraging amplitude and night length on capture nights, as well as temporal autocorrelation within each of the explanatory variables, with values $>0.7$ weakening the power of model selection to identify relevant factors (Tabachnick \& Fidell 1996). However, all Spearman correlations had values $<0.7$.

We performed Rayleigh's test using the package CircStats (Agostinelli 2009), model selection was performed in AlCcmodavg version 2.0-1 (Mazerolle 2013), and $t$ tests were conducted in Rcmr (Fox 2005) for R (R Development Core Team 2010). Time of capture for each bat was transformed into "minutes after sunset" using the program Moonphase 3.2 (see Esbérard 2012).

\section{RESULTS}

\section{Foraging activity of Molossus molossus}

We captured 248 adult individuals of $M$. molossus, with a sex ratio (male/female) of 0.36 , so we considered the studied population to represent a reproductive colony. We achieved 592 captures/recaptures, with 158 for males and 434 for females, and of which 405 represented roost emergence and 187 were roost return. Pregnant or lactating females were captured/recaptured on 40 or 47 occasions, respectively, with 24 pregnant or 36 lactating females leaving the roosts and 16 pregnant or 11 lactating females entering roosts. For males, 100 and 58 individuals were captured/ recaptured leaving or entering the roosts, respectively. As expected, the bats were predominantly crepuscular $(R=$ $0.76 ; p<0.01)$, with only 31 captures/recaptures $(5.24 \%)$ being recorded before sunset (Fig. 1). Most capture events

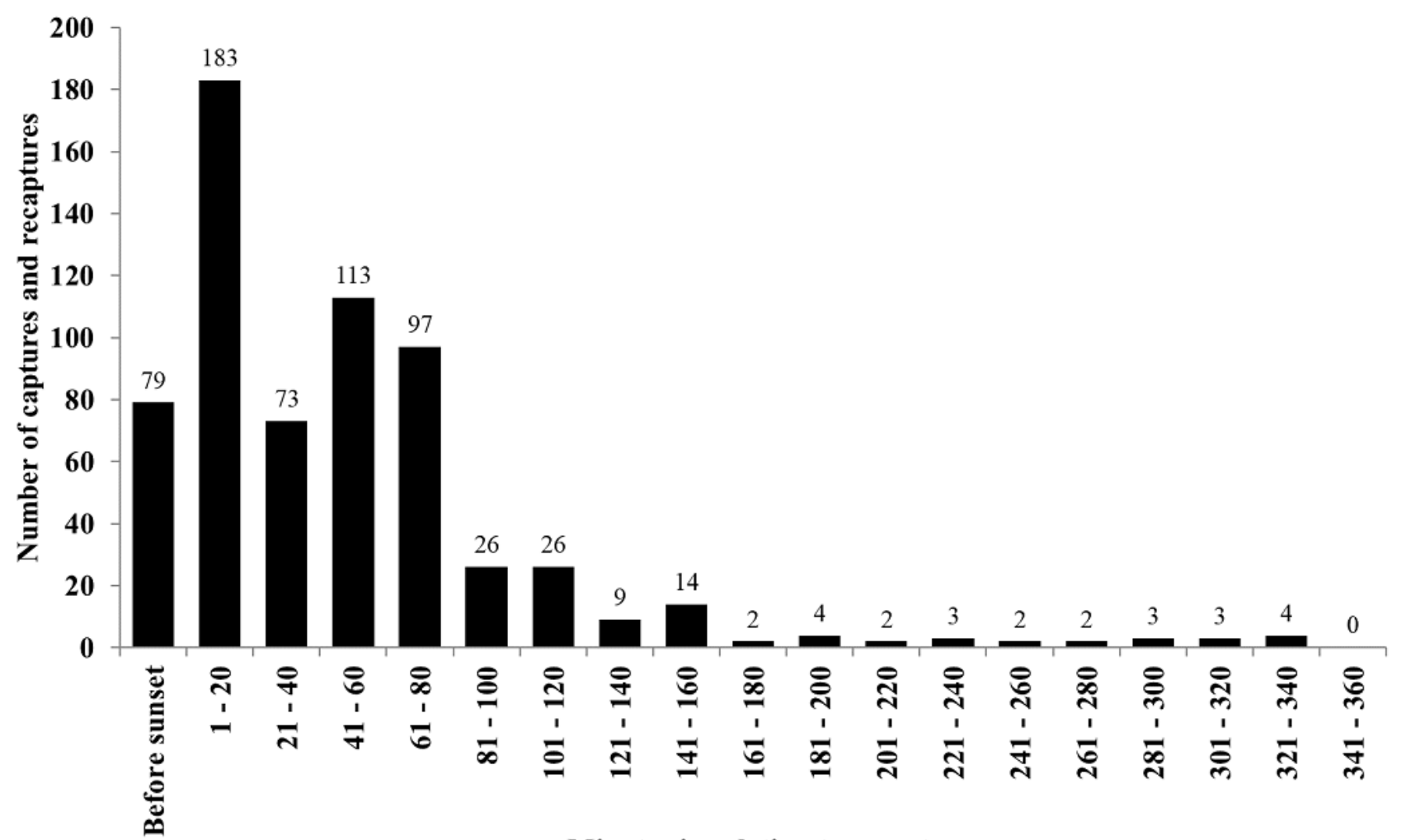

Minutes in relation to sunset

Fig. 1 - Captures/recaptures of Molossus molossus according to time after sunset at Gato Beach, Itacuruçá Island, Rio de Janeiro, southeastern Brazil (data collected from August 2009 to August 2011). 
Table 1 - Results of our generalized linear model showing variation in night length and foraging amplitude as a function of average body mass of bats upon returning to the roost. $\mathrm{K}$ - the number of covariates in the model; $\triangle \mathrm{AIC}$ - difference in AICc; AICcWt - the AIC weight.

\begin{tabular}{lcccc}
\hline & K & AICc & $\Delta$ AICc & AICcWt \\
\hline Model 1 - Night length & 3 & 54.854 & 0.000 & 0.839 \\
Model 2 - Night length + Foraging amplitude & 4 & 58.216 & 3.363 & 0.156 \\
Model 3 - Foraging amplitude & 3 & 65.221 & 10.367 & 0.005 \\
\hline
\end{tabular}

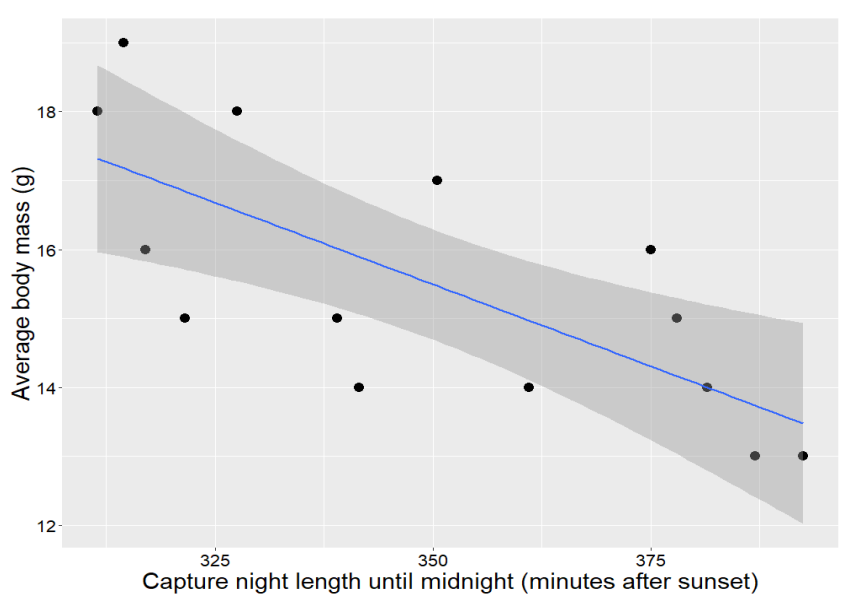

Fig. 2 - Relationship between capture night length until midnight (measured in minutes after sunset) and average body mass (in grams) of Molossus molossus returning to the roost. The bat colony was located at Gato Beach, Itacuruçá Island, Rio de Janeiro, southeastern Brazil, and it was monitored from August 2009 to August 2011.

( $n=408,68.92 \%$ ) occurred within 60 min of sunset. Initial emergence time varied from $7 \mathrm{~min}$ before sunset to $25 \mathrm{~min}$ after sunset on capture nights ( $4.81 \pm 8.94 \mathrm{~min})$. On average, bats emerged $37.37 \pm 51.71 \mathrm{~min}$ after sunset and returned to their roosts $73.30 \pm 59.66 \mathrm{~min}$ after sunset. Mean activity time outside the roosts was $35.93 \pm 9.92 \mathrm{~min}$.

\section{Insect consumption by Molossus molossus}

Animals captured emerging from the roosts had an average body mass of $14.70 \pm 1.50 \mathrm{~g}$. Individuals captured returning to the roosts had an average body mass of 15.50 $\pm 1.90 \mathrm{~g}$, representing a significant increase in mass $(0.80 \mathrm{~g}$ or $6.37 \pm 7.03 \% ; t=-3.30 ; p<0.005)$. The model selection showed that only night length (up to midnight) was important to explain the variation in average body mass of bats returning to the roost (Table 1 ). The average body mass of bats returning to the roost was negatively influenced by night length (Fig. 2, Estimate $=-0.04, \mathrm{SE}=0.01$, Confidence Intervals $=-0.07$ to $-0.02, \mathrm{t}$ value $=3.63, p=0.003$, Line equation $\left.-y=-11.032 x+520.85 ; R^{2}=0.52\right)$. We found that the difference in body mass between emerging and returning individuals was smaller on longer nights and vice versa. Considering that the average time bats spent outside the roosts in their first of two peaks of activity was 35.93 min and that they consumed, on average, $0.80 \mathrm{~g}$ during this period, we estimate that each individual $M$. molossus consumed an average of $22 \mathrm{mg} / \mathrm{min}$ of insects during that initial activity period.

\section{DISCUSSION}

\section{Activity of Molossus molossus}

Molossus molossus exhibited a crepuscular activity pattern the studied area, mirroring data for this species in Central America (Chase et al. 1991, Holland et al. 2011) and for another species of the same genus, $M$. rufus (Brown 1968), in North America (Fenton et al. 1998). This crepuscular activity coincides with the timing of greatest food availability, i.e., flying insects (Rautenbach et al. 1988, Chase et al. 1991, Jones \& Rydell 1994, Jung \& Kalko 2010, 2011). Typically, the activity peak for $M$. molossus that occurs close to sunset is more intense than the peak that occurs close to sunrise (Esbérard \& Bergallo 2010, Costa et al. 2011, Holland et al. 2011), perhaps reflecting activity peaks for the dipteran insects on which these bats prey (Chase et al. 1991, Jones \& Rydell 1994).

We found that the duration of activity outside roosts during the first half of the night $(35.93 \mathrm{~min}$ ) is close to the values reported for $M$. molossus by Dechmann et al. (2010) (37.55 min) and Holland et al. (2011) (50 min). We also note concordance in activity patterns between $M$. molossus and $M$. rufus, with these two species exhibiting similar preferences for habitat and roost sites (Esbérard 2011). Fenton et al. (1998) reported average M. rufus flight durations of 26.8 min in North America, whereas Marques (1986) cited average flight durations of 50.5 min for M. rufus in South America. These relatively short bouts of activity may be attributable to the considerable foraging efficiency of M. molossus (Fenton et al. 1998, Holland et al. 2011) and the bimodal activity pattern that allows these bats to return to their roosts to rest before engaging in a second flight near sunrise to forage again.

\section{Insect consumption by Molossus molossus}

Although pregnant and lactating females exhibit differences in terms of amounts of food ingested (Kunz et al. 1995), we did not factor this aspect into our analysis because of the low numbers of pregnant/lactating females we captured. Amounts of food consumed by $M$. molossus we present here $(0.80 \mathrm{~g}$ per individual or $22 \mathrm{mg} / \mathrm{min}$ ) are similar to data on M. rufus by Marques (1986), who reported insect consumption ranging from 10.67 to $19.00 \mathrm{mg} / \mathrm{min}$. However, Fenton et al. (1998) calculated average insect consumption for $M$. rufus of approximately $4.4 \mathrm{~g}$ in $26.8 \mathrm{~min}$ of activity, equating to a rate of $164.2 \mathrm{mg} / \mathrm{min}$. However, such comparisons should be interpreted with caution because despite having a similar biology to $M$. molossus 
(Esbérard 2011), M. rufus has a higher body mass and so requires greater food consumption.

We found a relationship between the increased average body mass upon returning to the roost and night length (to midnight) on capture nights, suggesting that these bats eat more when nights are shorter. Shorter nights occur in the period of year when environmental conditions (e.g., higher temperatures and rainfall) favor greater food availability and, consequently, higher bat activity (Williams 1940, Taylor 1963), i.e., corresponding to summer at our study site at $23^{\circ}$ southern latitude. Findings by Barros et al. (2014) corroborate this supposition through observations that in winter, on colder days, bats in southern Brazil exhibit reduced activity.

\section{CONCLUSIONS}

Here, we show that M. molossus in Brazilian Atlantic Forest exhibits greater activity soon after sunset during the first half of the night, representing a crepuscular activity pattern. Our study bats spent approximately 36 min outside of the roost and each individual bat consumed, on average, $22 \mathrm{~g} / \mathrm{min}$ of insects, with greater activity on short nights. Although we only sampled the first half of the total activity period of $M$. molossus, our data indicate higher insect consumption in summer during peak insect abundance. Our findings can contribute to further studies of bats as biological controls, which are warranted in Brazil because it is an important producer and exporter of agricultural products.

\section{ACKNOWLEDGMENTS}

We thank M. Fabian, L. Geise, A. Freitas, A. Cláudia Brasil, and I. Lima for their suggestions on a previous version of the manuscript. J. L. Luz, L. A. C. Gomes, E. C. Lourenço and M. Sant'Ana helped us in the field. G. P. Freitas thanks CAPES for an M.Sc. scholarship. W. D. C. thanks CAPES for a post-doctoral scholarship (Programa Nacional de Pós Doutorado, PNPD). L. M. C. thanks FAPERJ and CAPES for the post-doctoral scholarship (PAPDRJ - E-26/101.399/2014). C. E. L. Esbérard thanks FAPERJ for the "Jovem Cientista do Nosso Estado" scholarship (E-26/102.960/2012) and CNPq for the Productivity Fellowship Category 1D (Process \# 301061/2007-6). The present study was carried out under a special collection permit issued by IBAMA (Processes 1785/89-IBAMA and SISBIO 10356-1). The English of this final version of the manuscript was reviewed by John O’Brien.

\section{REFERENCES}

AGOSTINELLI, C. (2009). CircStats: Circular Statistics, S-plus original by U. Lund 'Topics in Circular Statistics' (2001). R package version $0.2-4$.

ANDRÉ, R. G. B., MARQues, V. S., PINHEIRO, F. M. A. \& FERRAUDO, A. S. (2008). Identificação de regiões pluviometricamente homogêneas no Estado do Rio de Janeiro, utilizando-se valores mensais. Revista Brasileira de Meteorologia, 23(4): 501-509. https://doi. org/10.1590/S0102-77862008000400009

ARANDAS, M. J. G. (2018). Ciclo reprodutivo dos machos de Myotis lavali e Molossus molossus (Mammalia: Chiroptera) em um fragmento de mata atlântica, nordeste do Brasil. Universidade Federal Rural de Pernambuco. Recife, Brazil. Universidade Federal Rural de Pernambuco.

AUDET, D. (1990). Foraging behavior and habitat use by a gleaning bat, Myotis myotis (Chiroptera: Vespertilionidae). Journal of Mammalogy, 71(3): 420427. https://doi.org/10.2307/1381955

BARCLAY, R. M. R. \& BRIGHAM, R. M. (1994). Constraints on optimal foraging: a field test of prey discrimination by echolocating insectivorous bats. Animal Behaviour, 48(5): 1013-1021. https://doi.org/10.1006/anbe.1994.1334

BARROS, M. A. S., MORAIS, D. B., ARAÚJO, M. R., CARVALHO, T. F., MATTA, S. L. P., PINHEIRO, E. C. \& FREITAS, M. B. (2013). Seasonal variation of energy reserves and reproduction in neotropical free-tailed bats Molossus molossus (Chiroptera: Molossidae). Braz. J. Biol., 73(3): 629-635. https://doi.org/10.1590/S151969842013000300022

BARROS, M. A. S., PESSOA, D. M. A. \& RUI, A. M. (2014). Habitat use and seasonal activity of insectivorous bats (Mammalia: Chiroptera) in the grasslands of southern Brazil. Zoologia, 31(2): 153-161. https://doi.org/10.1590/ S1984-46702014000200006

BIAVATTI, T., COSTA, L. M. \& ESBÉRARD, C. E. L. (2015). Morcegos (Mammalia, Chiroptera) em refúgios diurnos artificiais na região sudeste do Brasil. Mastozoología Neotropical, 22(2): 239-253.

BREVIGLIERI, C. P. B. (2011). Influência do dossel na atividade de morcegos (Chiroptera: Phyllostomidae) em três fragmentos no estado de São Paulo. Chiroptera Neotropical, 17(1): 817-825.

BROWN, J. H. (1968). Activity patterns of some Neotropical bats. Journal of Mammalogy, 49(4): 754-757. https:// doi.org/10.2307/1378737

BURNHAM, K. P. \& ANDERSON, D. R. (2002). Model selection and multimodel inference: a practical information theoretic approach, 2nd edition. ed.: Springer-Verlag, New York Inc. New York, United States of America, 515 pp. 
CARVALHO, W. D., FREITAS, L. N., FREITAS, G. P., LUZ, J. L., COSTA, L. M. \& ESBÉRARD C. E. L. (2011). Efeito da chuva na captura de morcegos em uma ilha da costa sul do Rio de Janeiro, Brasil. Chiroptera Neotropical, 17(1): 808-816.

CHASE, J., SMALL, M. Y., WEISS, E. A., SHARMA, D. \& SHARMA, S. (1991). Crepuscular activity of Molossus molossus. Journal of Mammalogy, 72(2): 414-418. https://doi.org/10.2307/1382116

CHRISTANTE, C. M., BEgUelinI, M. R., PUGA, C. C. I., NEGRIN, A. C., MORIELLE-VERSUTE, E., VILAMAIOR, P. S. L. \& TABOGA, S. R. (2013). Structure, histochemistry and seasonal variations of the male reproductive accessory glands in the Pallas's mastiff bat, Molossus molossus (Chiroptera: Molossidae). Reproduction, Fertility and Development, 27(2): 313-322. https://doi.org/10.1071/ RD13232

COSTA, L. M., LOURENÇO, E. C., LUZ, J. L., CARVALHO, A. P. F. \& ESBÉRARD, C. E. L. (2011). Activity of two species of free-tailed bats over a stream in southeastern Brazil. Acta Chiropterologica, 13(2): 405-409. https://doi. org/10.3161/150811011X624884

DECHMANN, D. K. N., KRANSTAUBER, B., GIBBS, D. \& WIKELSKI, M. (2010). Group hunting - A reason for sociality in molossid bats? Plos One, 5(2): e9012. https:// doi.org/10.1371/journal.pone.0009012

DUNN, J. C. \& WATERS, D. A. (2012). Altitudinal effects on habitat selection in two sympatric pipistrelle species. Mammalia, 76(4): 427-433. https://doi.org/10.1515/ mammalia-2012-0042

ESBÉRARD, C. E. L. \& DAEMON, C. (1999). Novo método para marcação de morcegos. Chiroptera Neotropical, 5(1-2): 116-117.

ESBÉRARD, C. E. L. (2006). Efeito da coleta de morcegos por noites seguidas no mesmo local. Revista Brasileira de Zoologia, 23(4): 1093-1096. https://doi.org/10.1590/ S0101-81752006000400016

ESBÉRARD, C. E. L. (2007). Influência do ciclo lunar na captura de morcegos Phyllostomidae. Iheringia, 97(1): 81-85. https://doi.org/10.1590/S0073-47212007000100012

ESBÉRARD, C. E. L. \& BERGALLO, H. G. (2008). Do bigger bats need more time to forage? Braz. J. Biol., 68(4): 819-822. https://doi.org/10.1590/S1519-69842008000400017

ESBÉRARD, C. E. L. \& BeRgALLO, H. G. (2010). Foraging activity of the free-tailed bat Molossus molossus (Chiroptera; Molossidae) in southeastern Brazil. Braz. J. Biol., 70(4): 1011-1014. https://doi.org/10.1590/S151969842010000500013

ESBÉRARD, C. E. L. (2011). Variação do tamanho de colônias de Molossus molossus e Molossus rufus no Estado do Rio de Janeiro, sudeste do Brasil. Neotropical Biology Conservation, 6(2): 71-77. https://doi.org/10.4013/ nbc.2011.62.01
ESBÉRARD, C. E. L. (2012). Activity and reproduction of Eptesicus brasiliensis (Chiroptera: Vespertilionidae) in the Rio de Janeiro State, Southeastern Brazil. Mammalia, 76(1): 49-55. https://doi.org/10.1515/mamm.2011.104

FABIÁN, M. E. \& MARQUES, R. V. (1989). Contribuição ao conhecimento da biologia reprodutiva de Molossus molossus (Pallas, 1766) (Chiroptera, Molossidae). Rev. Bras. Zool., 6(4): 603-610. https://doi.org/10.1590/ S0101-81751989000400005

FENTON, M. B., RAUTENBACH, I. L., RYDELL, J., ARITA, H. T., ORTEGA, J., BOUCHARD, S., HOVORKA, M. D., LIM, B., ODGREN, E., PORTFORS, C. V. et al. (1998). Emergence, echolocation, diet and foraging behavior of Molossus ater (Chiroptera: Molossidae). Biotropica, 30(2): 314-320. https://doi.org/10.1111/j.1744-7429.1998.tb00065.x

FOX, J. (2005). The R commander: a basic-statistics graphical user interface to R. Journal of Statistical Software, 14(9): 1-42. https://doi.org/10.18637/jss.v014.i09

FREITAS, G. P. (2012). Estudo de uma população de Molossus molossus (Pallas, 1766) (Mammalia, Chiroptera, Molossidae) na Praia do Gato, Ilha de Itacuruçá, Rio de Janeiro. Universidade Federal Rural do Rio de Janeiro. Rio de Janeiro, Brazil. Universidade Federal Rural do Rio de Janeiro.

HOLLAND, R. A., MEYER, C. F. J., KALKO, E. K. V., KAYS, R. \& WIKELSKI, M. (2011). Emergence time and foraging activity in Pallas' mastiff bat, Molossus molossus (Chiroptera: Molossidae) in relation to sunset/sunrise and phase of the moon. Acta Chiropterologica, 13(2): 399-404. https://doi.org/10.3161/150811011X624875

IBGE. (1992). Manual técnico da vegetação brasileira. Manuais Técnicos em geociências. ed.: IBGE. Rio de Janeiro, Brazil.

JONES, G. \& RYDELL, J. (1994). Foraging strategy and predation risk as factors influencing emergence time in echolocating bats. Phil. Trans. R. Soc. Lond. B., 346(1318): 445-455. https://doi.org/10.1098/rstb.1994.0161

JUNG, K. \& KALKO, E. K. V. (2010). Where forest meets urbanization: foraging plasticity of aerial insectivorous bats in an anthropogenically altered environment. Journal of Mammalogy, 91(1): 144-153. https://doi. org/10.1644/08-MAMM-A-313R.1

JUNG, K. \& KALKO, E. K. V. (2011). Adaptability and vulnerability of high flying Neotropical aerial insectivorous bats to urbanization. Diversity and Distributions, 17: 262274. https://doi.org/10.1111/j.1472-4642.2010.00738.x

KOEPPEN, W. (1948). Climatologia: con un estudio de los climas de la tierra. ed.: Fondo de Cultura Económica. Mexico, 496 pp.

KUNZ, T. H. \& ANTHONY, E. L. P. (1982). Age estimation and post-natal growth in the bat Myotis lucifugus. Journal of Mammalogy, 63(1): 23-32. http://doi. org/10.2307/1380667 
KUNZ, T. H., WHITAKER JR., J. O. \& WADANOLI, M. D. (1995). Dietary energetics of the insectivorous Mexican free-tailed bat (Tadarida brasiliensis) during pregnancy and lactation. Oecologia, 101: 407-415. https://doi. org/10.1007/BF00329419

KUNZ, T. H. \& ANTHONY, E. L. P. (1996). Variation in the timing of nightly emergence behavior in the Little brown bat, Myotis lucifugus (Chiroptera: Vespertilionidae). In: Contributions in Mammalogy: A memorial volume honoring Dr. J. Knox Jones Jr. ed.: Museum of Texas Tech University. Lubbock, Texas, United States of America, p.225-236.

KUNZ, T. H., ROBSON, S. K. \& NAGY, K. A. (1998). Economy of harem maintenance in the Greater spear-nosed bat, Phyllostomus hastatus. Journal of Mammalogy, 79(2): 631-642. https://doi.org/10.2307/1382993

LÓPEZ-BAUCELLS, A., ROCHA, R., ANDRIATAFIKA, Z., TOJOSOA, T., KEMP, J., FORBES, K. \& CABEZA, M. (2017). Roost selection by synanthropic bats in rural Madagascar: what makes non-traditional structures so tempting?. Hystrix, 28(1): 28-35. https://doi. org/10.4404/hystrix-28.1-12046

MACDONALD, D. W. (2001). The Encyclopedia of Mammals. ed.: Oxford University Press. Oxford, United Kingdom, $961 \mathrm{pp}$.

MARQUES, S. A. (1986). Activity cycle, feeding and reproduction of Molossus ater (Chiroptera: Molossidae) in Brazil. Boletim do Museu Paraense Emilio Goeldi, 2(2): 159-179.

MATTOS, C. L. V. (2005). Caracterização climática da Restinga de Marambaia. In: História natural da Marambaia. ed.: EDUR. Seropédica, Brazil, p.55-66.

MAZEROLLE, M. J. (2013). AlCcmodavg: model selection and multimodel inference based on (Q) AIC. https:// cran.r-project.org/web/packages/AICcmodavg/index. html

MCANEY, C. M. \& FAIRLEY, J. S. (1988). Activity patterns of the lesser horseshoe bat Rhinolophus hipposideros at summer roosts. Journal of Zoology, 216(2): 325-338. https://doi.org/10.1111/j.1469-7998.1988.tb02433.x

NOGUEIRA, M. R., DE LIMA, I. P., MORATELLI, R., TAVARES, V. C., GREGORIN, R. \& PERACCHI, A. L. (2014). Checklist of Brazilian bats, with comments on original records. Check List, 10(4): 808-821. https://doi.org/10.15560/10.4.808

NOGUEIRA, M. R., DE LIMA, I.P., GARBINO, G.S.T., MORATELLI, R., TAVARES, V. C., GREGORIN, R. \& PERACCHI, A. L. (2018). Updated checklist of Brazilian bats: versão 2018. Comitê da Lista de Morcegos do Brasil-CLMB. ed.: Sociedade Brasileira para o Estudo de Quirópteros (SBEQ).

NOWAK, R. M. (1994). Walker's. Bats of the World. ed.: The Johns Hopkins University Press. Baltimore, United States of America, $287 \mathrm{pp}$.
OLIVEIRA-SANTOS, L. G. R., ZUCCO, C. A. \& AGOSTINELLI, C. (2013). Using conditional circular kernel density functions to test hypotheses on animal circadian activity. Animal Behaviour, 85(1): 269-280. https://doi.org/10.1016/j. anbehav.2012.09.033

PACHECO, S. M., SODRÉ, M., GAMA, A. R., BREDT, A., CAVALLINI, E. M., MARQUES, R. V. \& BIANCONI, G. (2010). Morcegos urbanos: status do conhecimento e plano de ação para a conservação no Brasil. Chiroptera Neotropical, 16(1): 629-647.

RACEY, P. A. \& SWIFT, S. M. (1985). Feeding ecology of Pipistrellus pipistrellus (Chiroptera: Vespertilionidae) during pregnancy and lactation. I. Foraging Behaviour. Journal of Animal Ecology, 54(1): 205-215. https://doi. org/10.2307/4631

RAMÍREZ-CHAVES, H. E., MEJÍA-EGAS, O. \&ZAMBRANO-G, G. (2008). Anotaciones sobre dieta, estado reproductivo, actividad y tamaño de colonia del murciélago mastín común (Molossus molossus: Molossidae) en la zona urbana de Popayán, Departamento del Cauca, Colombia. Chiroptera Neotropical, 14(2): 384-390.

RAUTENBACH, I. L., KEMP, A. C. \& SCHOLTZ, C. H. (1988). Fluctuations in availability of arthropods correlated with microchiropteran and avian predator activities. Koedoe, 31(1): 77-90. https://doi.org/10.4102/koedoe.v31i1.486

REIS, N. R., PERACCHI, A. L., BATISTA, C. B. \& DE LIMA, I. P. (2017). História Natural dos morcegos brasileiros: chave de identificação de espécies. ed.: Technical Books Editora Ltda. Rio de Janeiro, Brazil, 480 pp.

RYDELL, J. (1993). Variation in Foraging Activity of an Aerial Insectivorous Bat during Reproduction. Journal of Mammalogy, 74(2): 503-509. https://doi. org/10.2307/1382411

SIKES, R. S. \& THE ANIMAL CARE AND USE COMMITTEE OF THE AMERICAN SOCIETY OF MAMMALOGISTS (ACUC). (2016). Guidelines of the American Society of Mammalogists for the use of wild mammals in research and education. Journal of Mammalogy, 97(3): 663-668. https://doi.org/10.1093/jmammal/gyw078

TABACHNICK, B. \& FIDELL, L. S. (1996). Using Multivariate Statistics. ed.: Harper Collins Publishers Inc. New York, United States of America, 983 pp.

TAYLOR, L. R. (1963). Analysis of the effect of temperature on insects in flight. Journal of Animal Ecology, 32(1): 99117. https://doi.org/10.2307/2520

WAI-PING, V. \& FENTON, M. B. (1989). Ecology of spotted bat (Euderma maculatum) roosting and foraging behavior. Journal of Mammalogy, 70(3): 617-622. https://doi.org/10.2307/1381434 
WELBERGEN, J. A. (2006). Timing of the evening emergence from day roosts of the grey-headed flying fox, Pteropus poliocephalus: the effects of predation risk, foraging needs, and social context. Behav. Ecol. Sociobiol., 60: 311. https://doi.org/10.1007/s00265-006-0167-3

WILLIAMS, C. B. (1940). An analysis of four years captures of insects in a light trap. Part II. The effect of weather conditions on insect activity; and the estimation and forecasting of changes inthe insect population. Transactions of the EntomologicalSocietyofLondon,90(8): 227-306. https://doi.org/10.1111/j.1365-2311.1940. tb03000.x
WINTER, Y. (1999). Flight speed and body mass of nectarfeeding bats (Glossophaginae) during foraging. Journal of Experimental Biology, 202: 1917-1930.

XAVIER, B. S., CARVALHO, W. D., DIAS, D., TABOSA, L. O., SANTOS, C. E. L. \& ESBÉRARD, C. E. L. (2018). Riqueza de morcegos (Mammalia: Chiroptera) em uma área de Floresta Atlântica montana na Serra da Mantiqueira, estado de Minas Gerais, sudeste do Brasil. Biota Neotrop., 18(2): e20170496. https://doi.org/10.1590/1676-0611bn-2017-0496

ZAR, J. H. (1996). Biostatistical analysis. ed.: Prentice Hall. New Jersey, United States of America, 662 pp. 